\title{
Factors Affecting The Collaborative Relationships in Tourism Supply Chain
}

\author{
Trang Thi Huyen Tran \\ Faculty of Tourism and Hospitality Management, National Economics University, Vietnam \\ tranhuyentrang.neu@gmail.com \\ * corresponding author
}

(Received July 1, 2021 Revised August 20, 2021 Accepted September 20, 2021, Available online December 1, 2021)

\begin{abstract}
Structural Equation Modeling was employed to examine the influence of several factors: trust, commitment, personal relationship, application of information technology in the chain, customer orientation policy, asset specificity and behavioral uncertainty to the collaborative relationships between travel companies and their suppliers in the tourism supply chain. The results indicate that the first four factors have direct and positive impacts on this collaborative relationship. Furthermore, the study also confirmed the nexus between trust as well as customer orientation policy and the commitment among members in the tourism supply chain.
\end{abstract}

Keywords: Trust, Commitment, Personal Relationship, Information Technology, Tourism Supply Chain

\section{Introduction}

\subsection{Theoretical aspect}

Tourism is a service industry which is cross-sectoral, cross-regional and highly socialized. In order to develop this industry into a key economic sector, it is necessary to strengthen the collaboration between travel companies and suppliers in the tourism supply chain. If the collaboration is effective, they can gain many benefits such as the provision of services with higher quality and lower prices; shortening the product life cycle in the times of recession, then encouraging the suppliers to pursue innovation, creativity, and after all, improving the quality of products and services to promptly meet customer requirements. To create core products, infused with national identity, of high quality and meet the diverse and demanding needs of visitors, travel companies need to establish and maintain effective partnerships with suppliers in the tourism supply chain.

The previous studies by Buhalis (2000), Medina-Muñoz and García-Falcón (2000) (cited in [1]) focused on the impact of certain factors on the cooperative relationship between hotels and travel agencies and tour operators. These studies only assess the cooperation between the parties and focuses on several individual factors affecting the relationship between the partners. These factors include trust, commitment, information technology that is not specific in the context of the tourism supply chain. However, they lack of research synthesis of identifiable factors that affect the collaboration between travel companies and suppliers in the tourism supply chain. Therefore, there exists a need for an overall evaluation of factors affecting the collaborative relationship of travel companies with suppliers in the supply chain tourism meet theoretical requirements.

\subsection{Practical aspect}

The Vietnam tourism industry in the last fifteen years has seen significant development with important results, encouraging and highly profitable businesses. Competition, however, always pushes tourism businesses towards creating more and more value-for-money products and services. Moreover, seasonality is an inherent characteristic of tourism products in any destination.

To resolve the challenges of seasonality in the tourism business, the tourism authorities and businesses need to formulate strategies to create linkages, cooperation between travel companies and tourism service suppliers such as tourism transport operators, accommodation facilities, dining, entertainment tours, shopping malls, etc. Moreover, an 
effective collaboration with suppliers in the supply chain, instead of merely transactional relationships, allows travel firms to better control their product quality, thereby foster trust of customers.

In reality, however, the importance of collaborative relationship of travel companies with suppliers in the tourism supply chain has not been of central concern to practitioners. Therefore, to enhance their strategic positions in the market place, travel companies need to establish and strengthen collaborative relationships with suppliers. Therefore, the author chose to study the topic "Factors affecting the collaborative relationship in tourism supply chain" in order to provide tourism managers and policy makers with relevant solutions. The author hopes these solutions would help them better govern collaborative relationship in the tourism supply chain.

\section{Literature Review}

\subsection{Basic concepts of collaborative relationships}

Travel company is an economic organization which has its own name, property and has a stable office and is registered by the law for the purpose of profitability through organizing, constructing, selling and running travel programs for tourists. In addition, travel company can conduct intermediary activities of selling products of travel suppliers or other general business activities to meet the needs of tourists from the first stage to the last stage of consumption. [2] Travel service providers are legal entities providing tourism products and services to tour operators so that these companies can provide travel packages to tourists. [2] Tourism supply chain can be defined as a network of tourism organizations supplying different components of tourism products / services such as flights and accommodation services for the distribution and marketing of the final tourism products at a specific tourism destination, and involving a wide range of participants in both the private and public sectors. [1]

\subsection{Classify the collaboration and collaboration relationship of travel companies with suppliers}

Horizontal collaboration is defined as the collaboration between two or more competing enterprises in the process of providing products and services to customers. Vertical collaboration is defined as a collaboration between two or more businesses, such as travel companies and travel agents, who share the responsibilities, benefits, and flow of information relating to customers for providing tourism services and input material suppliers to bring value to the end-users. Lateral collaboration characterizes both horizontal and vertical collaboration in order to achieve flexibility for partners through competition and resource sharing among stakeholders. Classification of collaboration in the field of tourism service business can be divided into horizontal collaboration, vertical collaboration and multi-dimensional collaboration. In this study, the focus is on collaboration, specifically the collaboration of travel companies with travel service providers.

\subsection{Theories of research on the cooperation of the travel company with the suppliers}

\subsubsection{Transaction cost economics - TCE}

Transaction cost economics theory applied in this study aims at explaining why businesses in the tourism supply chain must collaborate with each other. Since building trust simultaneously reduces transaction costs and control opportunistic behavior; trust is identified as a resource advantage.

\subsubsection{Social Capital Theory - SCT}

Social capital theory is employed to affirm the role of social capital in the development of collaboration relationship of travel companies with suppliers in the tourism supply chain. Thanks to social capital, collaborating parties can form interactions and social exchanges in which values, norms and beliefs are formed.

\subsubsection{Resource Based View - RBV}

Resource based view addresses the effect of resource factors and motivation for sharing resources between businesses on the collaboration between a travel company and its suppliers in the tourism supply chain [3]. Furthermore, the establishment of effective resource management mechanisms among partners is built on trust and commitment between businesses. Building of trust as well as commitment of the parties not only reduce transaction costs between 
collaborating partners but also create competitive advantage for businesses involved. This, in turn, helps strengthen the collaborative relationship between the parties [4].

\subsubsection{Resource Dependence Theory - RDT}

Regarding the relationship between enterprises, resource dependence theory is concerned with addressing how businesses reduce uncertainty and dependence on external partners [5]. This theory is applied in the research to support a proposition that the sharing of resources (information, knowledge, etc.) between enterprises can be built on trust and commitment.

\subsection{Factors measuring the collaborative relationship of travel companies with suppliers in the tourism supply chain}

In order to measure collaboration between the parties, [6] used a collaborative measurement model based on three components: information sharing, decision synchronization and incentive alignment. Information sharing refers to the process of collection and communication in time, updates to decision makers with updates for planning and controlling collaborative activities. Decision synchronization means making a joint decision during the planning process. Incentive alignment refers to the level at which partners share costs, risks, and benefits.

\subsection{Factors affecting the collaborative relationship of travel companies with suppliers in the tourism supply chain}

\subsubsection{Trust}

Trust has a significant influence on the travel company's collaboration with suppliers in the tourism supply chain for two reasons. First, trust in inter-firm transactions is a prerequisite for partners to gather information. Based on this information, partners can adapt to market changes in time, therefore minimizing risks [7]. Second, increasing mutual trust will reduce transaction costs as well as improve profitability and increase business efficiency [8].

\subsubsection{Commitment}

Commitment is the willingness of each party to invest in financial, physical or informational resources to maintain a relationship [9]. In the supply chain, commitment reflects partners' attitudes towards the development and maintenance of long-term and stable collaborative relationships [10]. In addition, commitment will produce the stability of the collaborative relationship and reduce the effects of market uncertainty.

\subsubsection{Guanxi/Personal relationship}

Personal relationship is understood as the connection of personal relationships to ensure the interests of the parties involved. It contains obligations and guarantees between the parties, thereby enhancing mutual understanding, regulating social relationships and establishing long-term business relationships. In addition, personal relationships play an important role in establishing legitimate outside relationships rather than improving internal performance. Thanks to personal relationships, businesses can add resources and reduce transaction costs [11].

\subsubsection{Customer orientation policy}

Customer orientation policy emphasizes understanding and meeting the needs of target customers [12]. For example, when customer needs change, customer-oriented businesses will actively collect, analyze and disseminate complete information on their customers. Moreover, customer orientation policy also helps promote collaboration among supply chain partners. It not only helps businesses access information flows more easily, but also facilitates the connectivity and simplification of business processes. 


\subsubsection{Application of information technology in the chain}

Application of information technology in the chain helps create a link between the partners involved in the supply chain because it allows companies to collect, process and transmit the information needed for making synchronized decision [13]. Application of information technology in the chain brings specific benefits such as: easy access to information, improvement of communication process between the parties in the chain, reduction of operating costs and delivery of better service quality. It also reduces the complexity of the chain and enables companies to maximize business efficiency [14].

\subsubsection{Asset specificity}

Asset specificity refers to investments in assets in a particular transaction that bring partners such benefits as lowering costs and improving product and service quality [15]. According to this theory, investing in specialized assets affects the efficiency of collaborative operations in the supply chain. In particular, when a partner dedicates an investment to human resource or material, it will incur transaction costs (for example, the cost of the negotiation increases as the parties establish contractual safeguards for protecting these investments).

\subsubsection{Behavioral uncertainty}

Effective supply chain management requires the establishment of a collaborative relationship between partners in order to maximize customer value and bring benefits to the participants [16]. These relationships not only help companies link business functions and business processes with high engagement [17], but can also reduce uncertainty by increasing the amount of shared information. This will facilitate access to resources and reduce negotiating costs, as well as the cost of finding new markets through which it can help reducing transaction costs.

\subsection{Theoretical research model and hypothesis}

The proposed research model is based on the identification of factors that influence each part of the collaborative relationship of travel companies with suppliers in the tourism supply chain, (including information sharing SC_1, decision synchronization SC_2 and incentive alignment SC_3). The author draws on studies by [18]; [6]; [9]; [19]. The results of in-depth interviews with experts help identify six key factors affecting the relationship: (1) asset specificity, (2) behavioral uncertainty, (3) trust, (4) commitment, (5) personal relationship, (6) application of information technology in the chain.

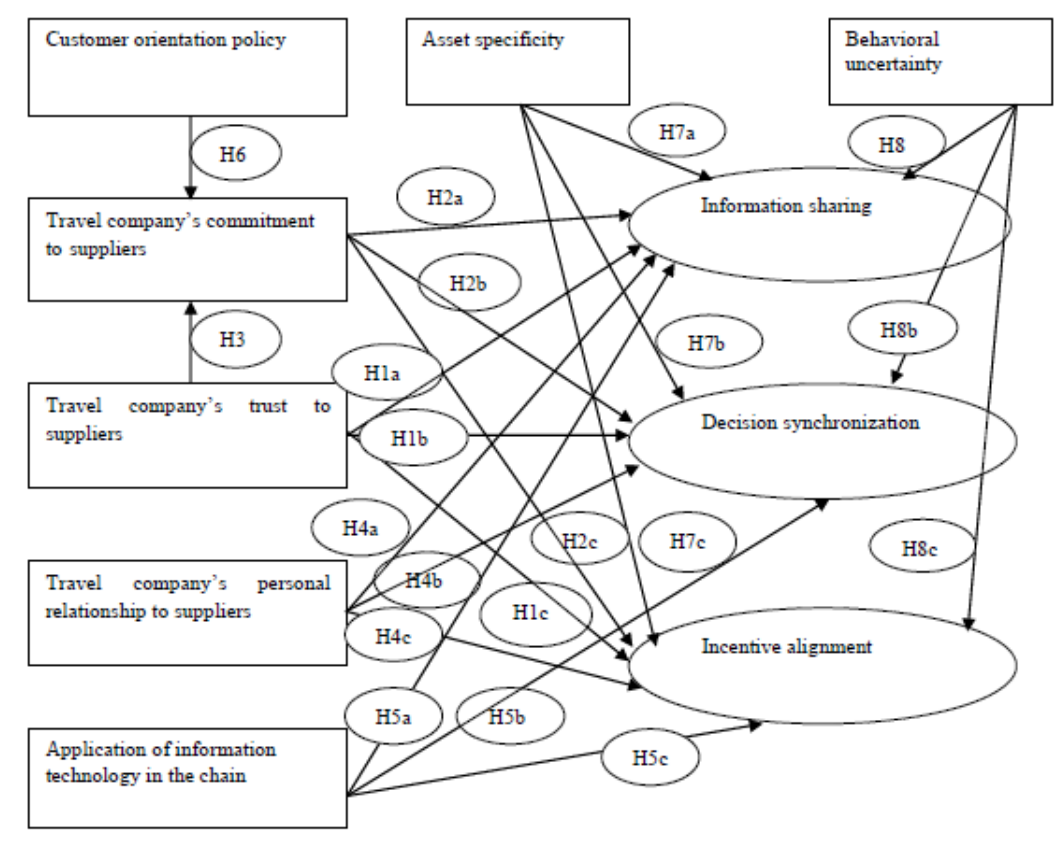

Figure. 1. Proposed research model 
Based on proposed research model (Figure 1), the author makes the following hypotheses:

Table. 1. Hypotheses

\begin{tabular}{|c|c|}
\hline Hypothesis & Content \\
\hline H1a & $\begin{array}{l}\text { Trust positively affects the information sharing of travel companies with suppliers in the } \\
\text { tourism supply chain. }\end{array}$ \\
\hline $\mathrm{H} 1 \mathrm{~b}$ & $\begin{array}{l}\text { Trust positively affects the decision synchronization of travel companies with suppliers in } \\
\text { the tourism supply chain. }\end{array}$ \\
\hline $\mathrm{H} 1 \mathrm{c}$ & $\begin{array}{l}\text { Trust positively affects the incentive alignment of travel companies with suppliers in the } \\
\text { tourism supply chain. }\end{array}$ \\
\hline $\mathrm{H} 2 \mathrm{a}$ & $\begin{array}{l}\text { Commitment positively affects the information sharing of travel companies with suppliers } \\
\text { in the tourism supply } \\
\text { chain. }\end{array}$ \\
\hline $\mathrm{H} 2 \mathrm{~b}$ & $\begin{array}{l}\text { Commitment positively affects the decision synchronization of travel companies with } \\
\text { suppliers in the tourism supply chain. }\end{array}$ \\
\hline $\mathrm{H} 2 \mathrm{c}$ & $\begin{array}{l}\text { Commitment positively affects the incentive alignment of travel companies with suppliers } \\
\text { in the tourism supply chain. }\end{array}$ \\
\hline $\mathrm{H} 3$ & $\begin{array}{l}\text { Trust positively affects the commitment of travel companies with suppliers in the tourism } \\
\text { supply chain. }\end{array}$ \\
\hline $\mathrm{H} 4 \mathrm{a}$ & $\begin{array}{l}\text { Personal relationship positively affects the information sharing of travel companies with } \\
\text { suppliers in the tourism supply chain. }\end{array}$ \\
\hline $\mathrm{H} 4 \mathrm{~b}$ & $\begin{array}{l}\text { Personal relationship positively affects the decision synchronization of travel companies } \\
\text { with suppliers in the tourism supply chain. }\end{array}$ \\
\hline $\mathrm{H} 4 \mathrm{c}$ & $\begin{array}{l}\text { Personal relationship positively affects the incentive alignment of travel companies with } \\
\text { suppliers in the tourism supply chain. }\end{array}$ \\
\hline $\mathrm{H} 5 \mathrm{a}$ & $\begin{array}{l}\text { Application of information technology in the chain positively affects the information } \\
\text { sharing of travel companies with suppliers in the tourism supply chain. }\end{array}$ \\
\hline $\mathrm{H} 5 \mathrm{~b}$ & $\begin{array}{l}\text { Application of information technology in the chain positively affects the decision } \\
\text { synchronization of travel companies with suppliers in the tourism supply chain. }\end{array}$ \\
\hline $\mathrm{H} 5 \mathrm{c}$ & $\begin{array}{l}\text { Application of information technology in the chain positively affects the incentive } \\
\text { alignment of travel companies with suppliers in the tourism supply chain. }\end{array}$ \\
\hline $\mathrm{H} 6$ & $\begin{array}{l}\text { Customer orientation policy positively affects the commitment of travel companies with } \\
\text { suppliers in the tourism supply chain. }\end{array}$ \\
\hline $\mathrm{H} 7 \mathrm{a}$ & $\begin{array}{l}\text { Asset specificity negatively affects the information sharing of travel companies with } \\
\text { suppliers in the tourism supply chain. }\end{array}$ \\
\hline $\mathrm{H} 7 \mathrm{~b}$ & $\begin{array}{l}\text { Asset specificity negatively affects the decision synchronization of travel companies with } \\
\text { suppliers in the tourism supply chain. }\end{array}$ \\
\hline $\mathrm{H} 7 \mathrm{c}$ & $\begin{array}{l}\text { Asset specificity negatively affects the incentive alignment of travel companies with } \\
\text { suppliers in the tourism supply chain. }\end{array}$ \\
\hline $\mathrm{H} 8 \mathrm{a}$ & $\begin{array}{l}\text { Behavioral uncertainty negatively affects the information sharing of travel companies with } \\
\text { suppliers in the tourism supply chain. }\end{array}$ \\
\hline $\mathrm{H} 8 \mathrm{~b}$ & $\begin{array}{l}\text { Behavioral uncertainty negatively affects the decision synchronization of travel companies } \\
\text { with suppliers in the tourism supply chain. }\end{array}$ \\
\hline $\mathrm{H} 8 \mathrm{c}$ & $\begin{array}{l}\text { Behavioral uncertainty negatively affects the incentive alignment of travel companies with } \\
\text { suppliers in the tourism supply chain. }\end{array}$ \\
\hline
\end{tabular}




\section{Research Methodology}

\subsection{Qualitative research methodology}

Qualitative research was conducted through in-depth interviews to collect information from different target groups. These groups included experts' (policy researchers and practitioners who have took part in the collaborative relationship between travel companies and suppliers in the tourism supply chain) opinions and comments from managers at various business positions of travel companies. The enterprises chosen represent diversified forms of ownership and scale of operations.

The selected qualitative research sample (in-depth interview) consisted of 8 people ( 2 experts working in tourism-related areas of government and 6 managers of travel companies in Hanoi). These people had a good understanding of the collaborative relationship of travel companies with suppliers in the tourism supply chain. They also offered insights into the factors affecting collaborative relationships. The uncomfortable random sample selection attempted to explore the factors affecting the travel company's collaboration with suppliers in the tourism supply chain.

\subsection{Quantitative research methodology}

Quantitative research aimed at testing proposed research model and hypotheses. The quantitative tools used in this study include reliability analysis (Cronbach's Alpha), exploratory factor analysis (EFA), confirmatory factor analysis (CFA) and structural equation modeling (SEM). Formal quantitative research employed direct survey questionnaire. This research was carried out through a direct interview of managers of travel companies in Hanoi.

In order to ensure the representativeness of the sample, the formal research sample applied the probabilistic sampling method. This method included a combination of stratified sampling as following catalog of travel company and a random method, particularly in the travel companies in Hanoi. 450 travel companies in Hanoi were selected as the subject of formal investigation since Hanoi had most of international travel enterprises in Vietnam, with the branches and representative offices throughout the provinces.

\section{Result Findings}

\subsection{Descriptive statistics}

450 questionnaires were distributed to travel companies in Hanoi by the contributors, during 30 days from April 1, 2016 to April 30, 2016. There were 389 questionnaires taken back, equivalent to a proportion of $86.4 \%$. After inspection and data cleaning, 370 were retained, accounting for $95.1 \%$ of the questionnaires collected.

\subsection{Reliability analysis - Cronbach's Alpha and Exploratory measurement results - EFA}

Through the measurement results of scales reliability in this model, there are seven factors that influence the collaborative relationship of the travel company with suppliers in the tourism supply chain, with cronbach's alpha > 0.6. Thus, the scales designed in this study reach the required coefficient reliability.

The Exploratory factor analysis uses the Principal Component Analysis method and Promax rotation to divide several groups. After eliminating the unsuitable variables, the components of the observed variables are required to have factor loadings $>0.5$ [20]; Bartlett test with $\mathrm{P}_{-}$value $=0.000 ; \mathrm{KMO}=0.916$. The results of this model showed that seven factors extracted from the eigenvalue were 1.199 and the cumulative of $63.714 \%$, and the cronbach's alpha is $>$ 0.7. However, to specifically confirm the scale reliability as well as ensuring the unidimensionality, convergent validity and discriminant validity of the scales, Confirmatory factor analysis is very necessary.

After completing Exploratory factor analysis, the two scales of Asset specificity (AS) and Behavioral uncertainty (BU) were grouped and renamed to Transaction Cost (TC), so the author needs to test the scale reliability. The results show that the Cronbach's Alpha coefficient calculated for the four observed variables of transaction cost factor is $0.872>0.6$, it can thus be said that the scale used to measure the transaction cost factor is suitable. 
Table. 2. Reliability analysis and Exploratory measurement results

\begin{tabular}{|l|l|l|l|l|}
\hline Items & $\begin{array}{l}\text { Number } \\
\text { Of Items }\end{array}$ & $\begin{array}{l}\text { Cronbach } \\
\text { 's Alpha }\end{array}$ & $\begin{array}{l}\text { Corrected Item } \\
\text {-Total } \\
\text { Correlation }\end{array}$ & $\begin{array}{l}\text { Minimum } \\
\text { Factor } \\
\text { Loading }\end{array}$ \\
\hline $\begin{array}{l}\text { The collaborative relationship of the } \\
\text { travel company with suppliers in the } \\
\text { tourism supply chain (SC), consists } \\
\text { of: }\end{array}$ & 7 & 0.893 & 0.573 & 0.505 \\
- Information sharing (SC_1) & 2 & & & \\
- Decision synchronization (SC_2) & 2 & 0.719 & 0.563 & 0.721 \\
- Incentive alignment (SC_3) & 3 & 0.711 & 0.552 & 0.650 \\
\hline $\begin{array}{l}\text { Travel company's trust to suppliers } \\
\text { (TR) }\end{array}$ & 6 & 0.777 & 0.566 & 0.505 \\
\hline Travel company's commitment to & 5 & 0.895 & 0.684 & 0.696 \\
suppliers (CO) & 4 & 0.894 & 0.690 & 0.673 \\
\hline Travel company's personal & & 0.713 & 0.728 \\
relationship to suppliers (PR) & 4 & 0.895 & 0.729 & 0.688 \\
\hline Application of information & & 0.888 & 0.731 & 0.782 \\
technology in the chain (IT) & 4 & 0.872 & 0.664 & 0.612 \\
\hline Customer orientation policy (CUO) & 4 & & \\
\hline Transaction cost (TC) & 4 & & \\
\hline
\end{tabular}

After performing the scales reliability and EFA analysis, the author adjusted hypothesis 7 and hypothesis 8 as follows:

H7a: Transaction cost negatively affects the information sharing of travel companies with suppliers in the tourism supply chain.

H7b: Transaction cost negatively affects the decision synchronization of travel companies with suppliers in the tourism supply chain.

H7c: Transaction cost negatively affects the incentive alignment of travel companies with suppliers in the tourism supply chain.

\subsection{Confirmatory Factor Analysis Results - CFA}

The results of the CFA analysis of adjustment research model (Tables 3) showed that all items had strong loadings with all values being significant at $\mathrm{p}<.001$ (all being above the acceptable factor loading $>0.35$ [20]. The initial results showed that the models fit the data well. Among comparative indicates, GFI, NFI, IFI, TLI, and CFI stand out to indicate that model fits data well. Furthermore, other model fit indices satisfy the condition of goodness-of-fit. Value of correlations from CFA model between variables show that all of correlation scores are lower than 0.85 , which means all of these constructs are different from each other.

Table. 3. Confirmatory Factor Analysis Results of adjustment research model

\begin{tabular}{|l|c|c|}
\hline Items & CCR & VE \\
\hline $\begin{array}{l}\text { The information sharing of travel companies with suppliers in the tourism supply } \\
\text { chain (SC 1) }\end{array}$ & 0.723 & 0.566 \\
\hline $\begin{array}{l}\text { The decision synchronization of travel companies with suppliers in the tourism } \\
\text { supply chain (SC 2) }\end{array}$ & 0.712 & 0.553 \\
\hline $\begin{array}{l}\text { The incentive alignment of travel companies with suppliers in the tourism supply } \\
\text { chain (SC 3) }\end{array}$ & 0.776 & 0.539 \\
\hline
\end{tabular}




\begin{tabular}{|l|c|c|}
\hline Travel company's trust to suppliers (TR) & 0.896 & 0.591 \\
\hline Travel company's commitment to suppliers (CO) & 0.901 & 0.647 \\
\hline Travel company's personal relationship to suppliers (PR) & 0.895 & 0.680 \\
\hline Application of information technology in the chain (IT) & 0.898 & 0.688 \\
\hline Customer orientation policy (CUO) & 0.888 & 0.665 \\
\hline Transaction cost (TC) & 0877 & 0.642 \\
\hline
\end{tabular}

\subsection{Structural Equation model and Hypothesis testing results}

The results of SEM analysis show that the model has 500 degrees of freedom with chi-squared $=1155.196(\mathrm{P}$-value $=$ $0.000)$. When adjusted with the degree of freedom $\mathrm{CMIN} / \mathrm{df}=2.310<3.0$. Furthermore, other indicators were satisfactory (TLI $=0.904 ;$ CFI $=0.914$; RMSEA $=0.06)$ [21]. Thus, the adjustment research model fits with the data collected.

According to test results of model (Figure 2), trust, commitment and personal relationship of travel companies to suppliers; application of information technology in the chain have a positive impact on the information sharing, decision synchronization and the incentive alignment of travel companies with suppliers in the tourism supply chain. The above four factors explain $46.1 \%$ of variation in information sharing; $55.1 \%$ of variation in decision synchronization and $55.4 \%$ of variation in incentive alignment. Of the four factors, the most influential factor on information sharing, decision synchronization, and incentive alignment of travel companies with suppliers in the tourism supply chain is travel company's commitment to the suppliers. Specifically, the commitment factor accounted for $40.8 \%$ of variation in information sharing; $53.1 \%$ of variation in decision synchronization and $43.4 \%$ of variation in incentive alignment of travel companies with suppliers in the tourism supply chain. In addition, travel company's trust in suppliers and customer orientation policy also have a positive impact on the travel company's commitment to suppliers; these two factors explain $28.7 \%$ of variation in travel company's commitment to suppliers. However, the transaction cost factor does not affect the information sharing, decision synchronization, and incentive alignment of travel companies with suppliers in the tourism supply chain.

Furthermore, the research results also showed that standardized weights are positive, thus trust, commitment and personal relationship of travel companies to the suppliers and application of information technology in the chain have a positive effect on the components of the travel company's collaboration with suppliers in the tourism supply chain (including information sharing, decision synchronization and incentive alignment). The factor that has the greatest impact on the information sharing, decision synchronization, and incentive alignment of travel companies with suppliers in the tourism supply chain is travel company's commitment to suppliers (standardized regression weights are $0.408,0.531$ and 0.434 , respectively), followed by travel company's trust to suppliers (standardized regression weights are $0.168,0.231$ and 0.244 , respectively), then travel company's personal relationship to suppliers (standardized regression weights are $0.217,0.158$ and 0.182 , respectively); and the application of information technology in the chain (standardized regression weights are $0.211,0.133$ and 0.221 , respectively). 




Figure. 2. Hypothesis testing results of adjustment research model

\section{Discussion and Recommendations}

\subsection{Discussions on research results}

Based on the research result of the study, the author has made some conclusions as below:

(1) Trust, commitment and personal relationship of travel companies with suppliers; application of information technology in the chain will have positive impacts on the elements of the collaborative relationship of travel companies with suppliers in the tourism supply chain (including information sharing, decision synchronization and incentive alignment).

(2) Commitment will be a key influencer to the collaborative relationship between travel companies and suppliers in the tourism supply chain, particularly on those decision synchronization elements. These results reaffirm the fact that higher commitment among the partners will result in better collaboration in plans and actions for maximization of benefits for all stakeholders.

\subsection{Proposed solutions for improved collaborative relationship of travel companies with suppliers in the tourism supply chain}

\subsubsection{To build up the trust of the travel companies with suppliers in the tourism supply chain}

Firstly, the efforts to boost collaboration of the travel companies and suppliers will be among the best solutions to minimize the uncertainties in the transactions as well as to increase trust between the stakeholders. To get the maximum benefits from the collaborative relationship, the stakeholders need to not only provide accurate, timely and sufficient information but also keep consistent updates on customer markets, distribution channels and consumption taste of the customers. 
Secondly, To boost the trust among the partners in the supply chain, the travel company needs to broaden its collaborative relationship with supplier, that is the representatives of partners - who have decision making authority or can influence the decision making process by suppliers.

Thirdly, To ensure secure the collaborative relationship of the travel companies with suppliers, the stakeholders need to put together a trust control mechanism based on the quality of services and customer values. To get this done, it is necessary to build up the trust of the travel companies with suppliers in order to create benefits, first for the enterprises involved in the partnership and then ultimately for sustaining sustainable development of the tourism industry.

\subsubsection{To enhance the commitment of the travel company with suppliers in the tourism supply chain}

Firstly, The suppliers in the tourism supply chain are the key influencers to the expenses and quality of commodities and services to be delivered to the tourists. The effective establishment and maintenance of long term collaborative relationship of the travel companies with suppliers, particularly the commitment between the collaborative partners should be built upon such common principles as: The stakeholders will find new ways to further expand the collaborative relationship between the stakeholders; to balance shared benefits; to establish well trusted relations among the supply chain members; to commit to sharing information for delivery of accurate projections about the tourist need variations as well as assurance of smooth information flows between the stakeholders.

Secondly, The commitment of the travel companies with suppliers will be the most important driver to the collaborative relationship. In order to sustain and further expand long-term and effective collaborative relationship, the travel company and suppliers will make efforts and invest in developing relations among stakeholders, especially the linkage and collaboration of the travel companies with accommodation service providers, restaurants, shopping and recreational centers; linkage and collaboration among enterprises in the construction of destinations, delivery of offerings and promotion of tourist services and products.

\subsubsection{To establish personal relationship of the travel companies with suppliers in the tourism supply chain}

Firstly, Based on psychological - socio-psychological traits, to establish and maintain personal relationship of the travel companies with suppliers, helping enterprises to boost up sales while reducing transaction costs as well as reducing uncertainties from the suppliers' side. Moreover, thanks to such personal relationship, enterprises may maximize their and suppliers' returns through taking advantage of the mutually shared resources.

Secondly, The enterprises need to make more investment in establishing and expanding relationship with individuals or partners' representatives, particularly people with decision making authorities. Therefore, the enterprises need to secure their critical relations with the partners via such actions as: to give gifts to partners on holidays, new year; to send regards and take care of partners during their establishment ceremonies, important events; to consistently keep in touch with partners in order to provide them with timely and considerate regards; to appoint qualified and well trained staff to establish and strengthen relations with the suppliers, etc.

\subsubsection{To develop customer orientation policy so as to bring outstanding values for customers}

Firstly, The travel companies will need to develop policies which seek to promote tourist products and meet tourists' need at the right time. Development of successful tourist products will not only help to meet the tourists' needs at the soonest but also a way to improve tourist products, reduce production cost and respond to variations in tourists' needs. Development of tourist products does not matter only to the travel companies, as this complex process requires the joint efforts of the suppliers in tourism supply train.

Secondly, The travel companies should take appropriate measures to excel their business performance, thereby, improving tourism service and satisfy tourists' needs. To attract tourists, the travel companies need to find new routes and tourist sites; to diversify their tourism agenda and offerings through examinations to design and formulate appealing and unique tourism programs. This will not only bring about added values for tourists but also maximize the benefits of their own, of traditional handicraft villages and local residents. 
5.2.5. Application of information technology in the chain in order to improved collaborative relationship of the travel company with suppliers in the tourism supply chain

Firstly, The details of tourism programs have been updated into the company's website which allows travel companies to sell tourism programs in a more flexible manner and better fit their preferences, taste and needs of tourists. Apart from that, travel companies may open new distribution channels via social media namely Facebook, YouTube, Twitter, LinkedIn, Google plus and Printerest to give tourists chance to compare the quality, service and prices of tours offered by various travel companies and then, in turn increase their journey experience.

Secondly, The travel companies and suppliers may create a database that takes hold of customer information to facilitate their marketing strategies. Thanks to the feedbacks given by the customers, the travel companies can cut down their marketing expenses and improve their business performance; the suppliers can provide better services and thereby best satisfying the tourists.

\subsection{Recommendations}

\subsubsection{Recommendations for management authorities}

The Ministry of Culture, Sports and Tourism need to put in place policies that seek to provide education, communication and information on the importance of collaborative relationship for travel companies and suppliers, as well as the role of trust and commitment to secure the sustainable linkage between travel companies and the suppliers. In addition, relevant management authorities (Vietnam National Administration of Tourism, Provincial and city Departments of Tourism) need to clarify the practical benefits that collaborative relationship can create and propose measures and methods of collaboration of travel companies with suppliers and relevant stakeholders as a way to improve the awareness of travel companies and suppliers on such collaborative relationship.

The Provincial Departments of Culture, Sports and Tourism need to work closely with each other in the issuance of business registration certificates, inspection and monitoring of travel companies' operations in their locales so as to ensure proper service quality and to prevent "insisting and/or forcing tourists on certain products or services". On the other hand, the competent authorities also need to attach special attention to the management of service prices; ensuring security and safety for tourists; ensuring food hygiene and safety; traffic related matters; environmental and overall landscape protection and at certain tourist sites, it is necessary to release websites for the purpose of promoting and making local tourism accessible to both local and foreign tourists.

\subsubsection{Recommendations for suppliers}

The suppliers need to standardize their skills and customer servicing capabilities, making them compliant with international standards as applicable for Vietnam context.

For travel agents, they need to develop the collaborative relationship with travel companies through the expansion of personal relationships with suppliers who play an important role in the tourism supply chain. In addition, travel agents need to perform proper intermediate functions, to constantly improve their counseling skills for tourists, and to implement the standard of service quality offered to tourists.

For tourism suppliers such as accommodation providers, restaurants, transport, entertainment activities as well as the other auxiliary services in the tourism supply chain, it is important to ensure the quality of the service as promised, and to constantly improve the capacity of cooperation with travel companies.

\subsubsection{Recommendations for travel companies}

The travel companies need to apply polices that seek to encourage personal relationship with partners who play critical roles in the supply chain. The travel companies need to provide their staff with skills on consultancy and sale of tour packages for tourists and provision of services and products with quality as per committed standards, making sure to create proper benefits to all relevant stakeholders in the supply chain. 


\subsection{Limitations and suggestions for the further study}

Firstly, data analysis reveals the impacts of concerned variables. However, this result is not applicable for other travel companies at national level since the survey only involved respondents from Hanoi-based travel companies. Therefore, future studies might widen the random samples to include nationwide travel companies. This would make it more reliable to have comparable analysis of travel companies in Central and Southern Vietnam as well.

Secondly, the study only focuses on some aspects of concepts or factors specific to the features of travel companies in Hanoi, based on qualitative studies. Many other factors, however, have not been taken into account. Hence, future researches may include various concepts that matter to the collaboration of travel companies with suppliers in the tourism supply chain, for example, the important role of public service providers and administrative state agencies in the tourism supply chain.

Thirdly, the study investigates the collaborative relationship of travel companies with suppliers instead of between travel companies and travel agents and tourists. Therefore, future researches may address in more details this collaborative relationship in order to create a more comprehensive view of this phenomenon.

\section{Conclusions}

This study synthesizes theories on the collaborative relationship of travel companies with suppliers in tourism supply chain. This helps figure out the factors of the collaboration and form the foundation for building research model of the study. The research results show that model fit well with the market survey data and reflect favorable impacts of the factors (trust, commitment, personal relationship, customer orientation policy and application of information technology in the chain) on the elements of the collaborative relationship of travel companies with suppliers in the tourism supply chain (information sharing, decision synchronization and incentive alignment).

The study also proposes suggestions and recommendations for better collaboration of travel companies with suppliers in the tourism supply chain. These are expected to help strengthen travel companies' strategic position in the market place. Establishing good relations with suppliers helps travel companies gain customer confidence. This also allows them to better control and deliver their service quality than establishing collaborative relationship with enterprises outside the supply chain. This will end up bringing more added values for customers. It is, therefore, essential to establish collaborative relationship of the travel companies with suppliers in the tourism supply chain in Vietnam context.

\section{References}

[1] Zhang, X., Song, H., and Huang, G.Q. 2009. Tourism supply chain management: A new research agenda, Tourism Management, 30, 345-358.

[2] Mạnh, V. N. and Chương, H. C. 2009. Quản trị kinh doanh lũ hành, NXB Đại học Kinh tế Quốc dân.

[3] Cao, M. and Zhang, Q. 2011. Supply chain collaboration: Impact on collaborative advantage and firm performance, Journal of Operations Management, 29(3), 163-180.

[4] Grover, V. and Malhotra, M. K. 2003. Transaction cost framework in operations and supply chain management research: theory and measurement, Journal of Operations Management, 21(4), 457-474.

[5] Hillman, A. J., Withers, M. C., and Collins, B. J. 2009. Resource dependence theory: A review, Journal of Management, 35(6), 1404-1427.

[6] Simatupang, T.M. and Sridharan, R. 2004. The collaboration index: a measure for supply chain collaboration, International Journal of Physical Distribution \& Logistics Management, 35(1), 44-62.

[7] Chen, W., Zhang, X., Peng, C. and Xu, L. 2012. Supply chain partnerships, knowledge trading and cooperative performance: an empirical study based on Chinese manufacturing enterprises, Journal of Cambridge Studies, $7(2), 129-149$.

[8] Mayer, R.C., Davis, J. and Schoorman, F.D. 1995. An integrative model of organizational trust, Academy of Management Review, 20(3), 709-34. 
[9] Morgan, R. M. and Hunt, S. D. 1994. The commitment-trust theory of relationship marketing, Journal of Marketing, 53(3), 20-38.

[10] Anderson, E.W. and Weitz, B. 1992. The use of pledges to build and sustain commitment in distribution channels, Journal of Marketing Research, 58, 1-15.

[11] Park, S. H. and Luo, Y. 2001. Guanxi and Organizational Dynamics: Organizational Networking in China Firms, Strategic Management Journal, 22(5), 455-477.

[12]Zhou, K.Z., Brown, J.R. and Dev, C.S. 2009. Market orientation, competitive advantage, and performance: a demand-based perspective, Journal of Business Research, 62, 1063-1070.

[13]Li, X., Goldsby, T. J., and Holsapple, C. W. 2009. Supply chain agility: scale development, International Journal of Logistics Management, 20(3), 408-424.

[14] Wu, F., Yeniyurt, S., Kim, D. and Cavusgil, S.T. 2006. The impact of information technology on supply chain capabilities and firm performance: A resource-based view, Industrial Marketing Management, 35, 493 - 504.

[15] Williamson, O. E. 1985. The Economic Intstitutions of Capitalism, New York: Free Press.

[16]Fugate, B. S., Mentzer, J. T. and Stank, T. P. 2010. Logistics Performance: Efficiency, Effectiveness, and Differentiation, Journal of Business Logistics, 31, 43-61.

[17]Ellinger, A. E., Patricia J. D. and Scott B. K. 2000. The relationship between marketing/ logistics interdepartmental integration and performance in U.S. manufacturing firms: an empirical study, Journal of Business Logistics, 21(1), 1-22.

[18]Piboonrungroj, P. and Disney, S.M. 2009. Tourism supply chains: A conceptual framework, Proceedings of the Phd Networking Conference on Exploring Tourism III, July 1-2, 2009, Nottingham, UK, 132-149.

[19] Nyaga, G. N., Whipple, J. M. and Lynch, D. F. 2010. Examining supply chain relationships: Do buyer and supplier perspectives on collaborative relationships differ?, Journal of Operations Management, 28(2), 101 114.

[20]Hair, J., Black, W., Babin, B., Anderson, R., and Tatham, R. 2006. Multivariate data analysis (6th ed.), Uppersaddle River, New York, Pearson Prentice Hall.

[21]Browne, M.W. and Cudeck, R. 1992. Alternative ways of assessing model fit, Sociological Methods and Research, 21, 230-58. 